\title{
Fleksibilitas Sistem Informasi dari Perspektif Pengguna Dan Pengembang Sistem Informasi
}

\author{
Yasir Arafat \\ Magister Teknik Elektro Fakultas Teknik Universitas Tanjungpura, \\ Program Studi Teknik Informatika, Jurusan Teknik Elektro, \\ Politeknik Negeri Pontianak \\ e-mail : Presiden_plo@yahoo.com
}

\begin{abstract}
Sistem informasi (SI) ditujukan untuk mendukung pelaksanaan proses bisnis suatu unit organisasi. Untuk meningkatkan kinerja proses bisnis dapat didekati dengan meningkatkan efisiensi dan efektivitas dari sistem informasi pendukungnya. Salah satu faktor penting untuk meningkatkan kinerja sistem informasi adalah dengan menggunakan asas fleksibilitas pada sistem informasi tersebut.

Yang menjadi pertanyaan dalam tulisan ini adalah bagaimana pandangan dari pengguna dan pengembang sistem dan apa peran dari kedua pihak tersebut dalam kesuksesan penerapan asas fleksibilitas pada sistem informasi.

Tulisan ini juga menyertakan studi kasus sederhana untuk melihat hubungan antara pengguna dan pengembang sistem informasi.

Sistem informasi (SI) ditujukan untuk mendukung pelaksanaan proses bisnis suatu unit organisasi. Untuk meningkatkan kinerja proses bisnis dapat didekati dengan meningkatkan efisiensi dan efektivitas dari sistem informasi pendukungnya. Salah satu faktor penting untuk meningkatkan kinerja sistem informasi adalah dengan menggunakan asas fleksibilitas pada sistem informasi tersebut.

Yang menjadi pertanyaan dalam tulisan ini adalah bagaimana pandangan dari pengguna dan pengembang sistem dan apa peran dari kedua pihak tersebut dalam kesuksesan penerapan asas fleksibilitas pada sistem informasi.

Tulisan ini juga menyertakan studi kasus sederhana untuk melihat hubungan antara pengguna dan pengembang sistem informasi.
\end{abstract}

Keywords- fleksibilitas, sistem informasi, proses bisnis, pengguna SI, pengembang SI.

\section{Pendahuluan}

Sistem Informasi dimanfaatkan oleh suatu organisasi atau unit di suatu organisasi untuk membantu kegiatan operasionalnya sehari-hari dan membantu manajemen dalam mengambil suatu keputusan. Sistem informasi yang dibangun harus selaras (align) dengan proses bisnis yang berlaku. Proses pembangunan sistem informasi dari analisis, perancangan, hingga implementasi dilaksanakan dengan mengacu kepada tujuan alignment tersebut.
Proses bisnis yang diacu biasanya bersifat dinamis, yaitu memiliki parameter-parameter atau variabel-variabel yang menyebabkan banyaknya variasi pelaksanaan proses bisnis tersebut. Variasi ini harus dapat didukung pula oleh sistem informasi yang terkait.

Selain itu, proses bisnis harus bersifat adaptif terhadap perubahan yang harus diadopsi, misalnya karena perkembangan teknologi, perubahan struktur organisasi, dan lainnya. Perubahan proses bisnis ini tentu tentu saja bukan perubahan yang fundamental yang mengubah inti dari bisnis organisasi. Hal ini akan berhubungan secara langsung dengan sifat adaptif dari sistem informasi pendukungnya.

Pada pelaksanaan pembangunan sistem informasi, baik yang dilaksanakan secara inhouse maupun outsource ke pihak ketiga, 2 (dua) pihak yang terlibat adalah pihak pengguna dan pihak pengembang sistem. Yang menjadi pertanyaan untuk diteliti adalah bagaimana pandangan dari kedua belah pihak tersebut dalam melihat fleksibilitas sistem informasi terhadap dinamisasi dan perubahan proses bisnis organisasi.

Tulisan ini bermaksud menyampaikan gambaran umum dari fleksibilitas sistem informasi dari perspektif pengguna dan pengembang sistem informasi, serta studi kasus terhadap tinjauan tersebut pada sistem informasi mahasiswa.

Bagian pertama dari tulisan ini menjelaskan secara singkat tentang dinamisasi dan perubahan proses bisnis dan hubungannya dengan sistem informasi, sementara bagian kedua memaparkan tinjauan umum pembangunan sistem informasi.

Bagian ketiga yang merupakan inti dari tulisan ini menjelaskan fleksibilitas sistem informasi dari perspektif pengguna dan pengembang sistem informasi, sementara bagian keempat memanfaatkan hasil yang dipaparkan pada bagian ketiga untuk studi kasus sistem informasi mahasiswa. Sebagai penutup, bagian kelima dari tulisan ini memaparkan beberapa kesimpulan dan saran untuk pelaksanaan penelitian selanjutnya.

\section{TeoriDasar}

\section{a. Fleksibilitas Sistem Informasi}

Kamus Merriam-Webster

mendefinisikan fleksibilitas sebagai: (1) kemampuan menjadi fleksibel, (2) patuh terhadap pengaruh, dan (3) dicirikan dengan kesiapan atas kemampuan untuk melakukan adaptasi terhadap kebutuhan yang baru, berbeda, atau berubah [6, hal 4]. Dari sini dapat diambil kesimpulan bahwa 
fleksibilitas adalah kemampuan organisasi dalam menyikapi atau merespon terhadap perubahan lingkungan, baik internal maupun eksternal.

Sedangkan fleksibilitas sistem informasi dapat diartikan sebagai kemampuan dari sebuah sistem informasi dalam menyikapi atau merespon kebutuhan pengguna akan requirement yang baru, berbeda, atau berubah.

Fleksibilitas dapat mempengaruhi efisiensi dan efektifitas operasional bagi sistem informasi di perusahaan, akan tetapi faktor fleksibilitas ini jarang sekali menjadi faktor yang dipertimbangkan secara eksplisit dalam perancangan dan implementasi sistem informasi. [2, hal 1]

Dalam konteks sistem informasi, fleksibilitas dapat dipandang dari berbagai sisi atau aspek, antara lain: metode, produk, strategi, proses, dan sistem [4, hal 3-5]. Aspek metode dan produk fokus pada pemanfaatan atau penggunaan sistem informasi, yang tentunya berkaitan arsitektur sistem dan pemeliharaan (maintenance) sistem. Aspek strategi, proses, dan sistem terkait dengan sumber daya manusia [4, hal 4].

Sedangkan menurut [1, hal 8-11], strategi dari fleksibilitas sistem informasi dapat dibagi dalam 2 (dua) jenis, yaitu flexibility-to-use dan flexibility-to-change.

\section{b. Karakteristik Proses Bisnis}

Sistem informasi digunakan untuk mendukung proses bisnis. Karena fokus dari tulisan ini adalah fleksibilitas sistem informasi, yang tentunya ditujukan untuk memperbaiki kinerja proses bisnis, maka kita harus memperhatikan kinerja dari proses bisnis dan menjadikan karakteristik dari proses bisnis sebagai salah satu bagian dari analisis fleksibilitas sistem informasi.

Beberapa karakteristik proses bisnis yang digunakan adalah [1, hal 4-6]: ketidakpastian (uncertainty), keanekaragaman (variability), dan keterbatasan waktu (time-criticality).

Dengan asumsi bahwa proses bisnis yang ditetapkan adalah yang terbaik bagi suatu organisasi, maka proses bisnis tersebut harus dilaksanakan dengan sebaikbaiknya (kinerja yang tinggi), dengan selalu memperhatikan karakteristik proses bisnis, serta memastikan segala dukungan proses bisnis (termasuk sistem informasi) menuju ke arah yang sama.

Untuk menjawab hal tersebut, dapat dilihat adanya korelasi antara karakteristik proses bisnis dengan strategi fleksibilitas sistem informasi, yaitu:

1. Karakteristik uncertainty berkorelasi dengan strategi flexibility-to-change,

unsur ketidakpastian dari proses bisnis menyebabkan adanya kemungkinan perubahan proses bisnis, sehingga sistem informasi haruslah relatif mudah untuk berubah (bersifat adaptif).

2. Karakteristik variability berkorelasi dengan strategi flexibility-to-use

Unsur keberagaman dari proses bisnis menyebabkan sistem informasi yang ada haruslah menyediakan berbagai macam "alur" penggunaan (bersifat dinamis), misalnya pengguna dapat mengubah layout laporan.
Kedua strategi tersebut ditujukan untuk mendukung pelaksanaan proses bisnis yang bersifat time-criticality.

Pada tulisan ini, penulis mencoba untuk meninjau perspektif dari pihak-pihak utama yang terlibat dalam pemanfaatan strategi fleksibilitas sistem informasi untuk perbaikan kinerja proses bisnis. Penulis membagi pihakpihak yang terlibat ke dalam dua golongan besar, yaitu pengguna dan pengembang sistem informasi. Yang dimaksud dengan pengguna di sini adalah operator, manajer, investor, dan lainnya yang merupakan bagian dari organisasi yang memanfaatkan sistem informasi tersebut, atau dapat disebut juga organisasi itu sendiri.

Dengan adanya tinjauan ini diharapkan adanya saling pengertian dan kerjasama yang baik antara pengguna dengan pengembang sistem informasi dalam rangka perbaikan kinerja proses bisnis.

\section{c. Pembangunan SistemInformasi}

Sebelum pelaksanaan pembangunan sebuah sistem informasi, disepakati metode pembangunan sistem informasi yang digunakan terlebih dahulu di antara pengguna dan pengembang sistem informasi. Metode yang dipilih dapat mempengaruhi faktor keterlibatan pengguna dan faktor biaya, waktu, dan sumber daya yang harus dipersiapkan oleh pengguna.

Adapun tahap-tahap pengembangan yang umum digunakan pada beberapa metode pembangunan perangkat lunak adalah: analisis, perancangan, implementasi, pengujian, Instalasi, pelatihan, serta pemeliharaan.

Berikut akan dipaparkan setiap tahapan pembangunan perangkat lunak tersebut dan hubungannya dengan bahasan fleksibilitas sistem informasi.

1. Analisis

Pada tahap ini, akan ditentukan sampai sejauh mana tingkat fleksibilitas sistem informasi yang akan diimplementasikan. Hal ini berkaitan erat dengan anggaran dana dan waktu yang tersedia untuk mengembangkan sistem informasi, serta kesiapan sumber daya manusia yang akan menggunakannya kelak.

\section{Perancangan}

Tahap perancangan merupakan tahap yang paling penting dalam mempersiapkan fleksibilitas sistem informasi sesuai dengan tingkat fleksibilitas yang diinginkan dari tahap analisis, karena pada tahap inilah suatu sistem informasi dirancang sedemikian rupa sehingga sistem informasi tersebut dapat menjawab kebutuhan dinamisasi dan perubahan proses bisnis. Misalnya pada perancangan basis data, bagaimana struktur data yang baik sehingga mudah dalam melakukan skabilitas data. Atau pada perancangan antarmuka, bagaimana caranya agar desain antarmuka yang dikembangkan dapat memenuhi aspek dinamisasi proses bisnis.

\section{Implementasi}

Merupakan tahap pengkodean sistem informasi sesuai hasil perancangan. 


\section{Pengujian}

Dari sisi fleksibilitasnya, pada tahap ini akan diuji seluruh aspek dinamisasi proses bisnis yang diimplementasikan, serta akan diuji tingkat adaptasi atau tingkat kemudahan sistem menerima perubahan proses bisnis.

5. Instalasi

Instalasi sistem informasi sehingga sistem informasi tersebut siap untuk digunakan.

6. Pemeliharaan

Pada tahap ini, pengguna mulai memanfaatkan sistem informasi yang telah dibangun. Permasalahan fleksibilitas sistem informasi mungkin akan dialami oleh pengguna. Kehandalan produk yang dihasilkan akan teruji pada tahap ini.

\section{d. Perspektif Pengguna}

Dari perspektif pengguna, hal yang akan menjadi perhatian adalah:

a. Sistem informasi yang dihasilkan harus dapat mendukung operasional proses bisnis dan dapat meningkatkan kinerja proses bisnis itu sendiri.

b. Sistem informasi yang dihasilkan sedapat mungkin mudah untuk menerima perubahan.

c. Jika dibutuhkan perbaikan atau penambahan fitur sistem informasi, maka proses itu sedapat mungkin menggunakan waktu yang sesingkat mungkin.

\section{e. Perspektif Pengembang}

Sedangkan dari perspektif pengembang, hal yang akan menjadi perhatian antara lain:

a. Memilih metode perancangan dan aristektur sistem informasi yang akan digunakan untuk membuat sistem informasi yang fleksibel.

b. Membuat sistem informasi yang fleksibel membutuhkan waktu dan biaya yang besar. Hal ini dapat menjadi ancaman, akan tetapi dapat juga menjadi peluang, baik peluang dalam pengembangan sistem yang baru maupun peluang pekerjaan pemeliharaan sistem tersebut.

c. Semakin fleksibel suatu sistem informasi, maka pengguna biasanya semakin sulit dalam penggunaan sistem informasi tersebut. Oleh karena itu, antarmuka yang baik merupakan sesuatu yang penting untuk diperhatikan oleh pengembang.

Dengan memahami perspektif dari pihak yang lain (pengguna paham terhadap perspektif pengembang dan sebaliknya), maka masing-masing pihak harus menyediakan hal-hal sebagai berikut:

1. Pihak Pengguna

- Biaya dan waktu pengembangan yang relatif lebih besar jika dibandingkan dengan sistem informasi yang tidak/kurang memperhatikan konsep fleksibilitas.

- Menyediakan operator dengan IT literacy yang cukup tinggi (merekrut operator baru atau memberikan pelatihan bagi operator yang lama, jika kemampuan IT-nya dirasakan masih kurang memadai), karena sistem informasi yang fleksibel akan lebih sulit dalam penggunaannya.
- Berkomitmen tinggi untuk membantu pengembang dalam mengembangkan sistem informasi, terutama pada tahap analisis dan pengujian sistem.

Hubungan antara tingkat fleksibilitas sistem yang diinginkan dengan biaya, waktu, dan kemampuan SDM yang harus disiapkan oleh pengguna sistem dapat dilihat pada gambar di bawah ini.

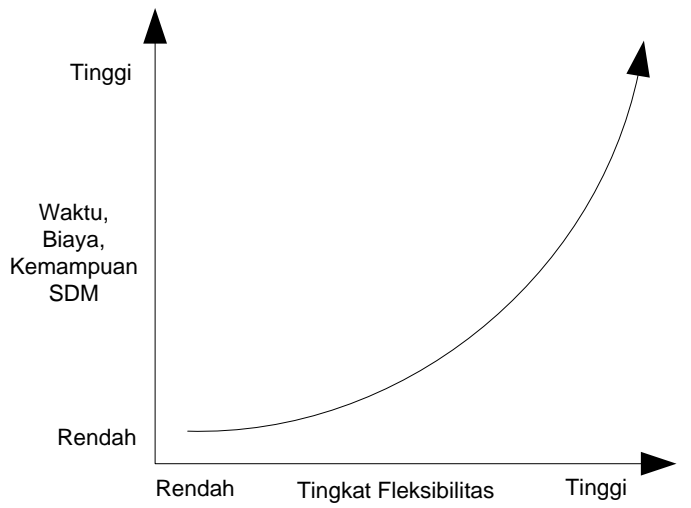

Gambar 1 Fleksibilitas Sistem Informasi dari Perspektif Pengguna

2. Pihak Pengembang

- Usaha yang lebih besar dalam melakukan perancangan arsitektur dan modularitas sistem informasi. Sistem informasi yang akan dikembangkan harus dirancang sedemikian rupa sehingga dapat memenuhi aspek strategi fleksibilitas sistem informasi, yaitu flexibility-to-use dan flexibility-to-change.

- Seperti yang disebutkan sebelumnya, aspek fleksibel pada sistem informasi dapat membuat sistem informasi tersebut lebih sulit untuk digunakan. Tim pengembang, khususnya user interface designer harus memberikan usaha yang lebih dalam merancang antarmuka sistem informasi.

- Usaha yang lebih besar dalam melakukan implementasi sistem karena harus mengakomodasi hasil perancangan sistem yang lebih kompleks.

- Usaha yang lebih besar dalam pengujian sistem informasi. Dalam pengujian fleksibilitas sistem informasi, harus dirancang suatu studi kasus yang komprehensif untuk menjamin bahwa aspek fleksibel dalam sistem informasi tidak menambah bug dalam sistem.

Membuat dokumentasi teknis yang baik.

Untuk itu, tim pengembang harus melibatkan setiap profesi dalam pengembangan sistem informasi pada tempatnya, antara lain: team leader, system analyst, system architect, user interface designer, senior \& junior programmer, system test engineer, dan documentator.

Hubungan antara tingkat fleksibilitas sistem dengan usaha yang diberikan oleh tim pengembang dalam mengembangkan sistem (termasuk ketersediaan profesi-profesi pengembangan sistem), dapat dilihat pada gambar di bawah ini. 


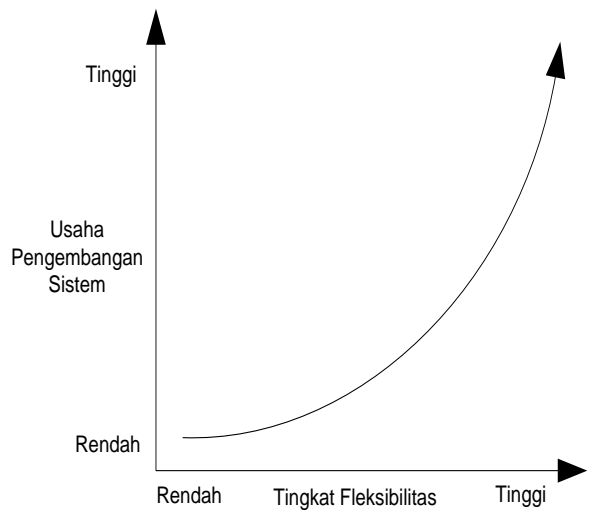

Gambar 2 Fleksibilitas Sistem Informasi dari Perspektif Pengembang

\section{Analisa dan Hasil}

Pada bagian ini, penulis akan memaparkan studi kasus yang melibatkan penulis dalam pengembangannya, yaitu Sistem Informasi Manajemen Pelatihan (SIMP) pada salah satu unit di instansi pemerintahan. Pelatihan adalah bisnis utama dari unit itu. Akan dibahas perspektif pengguna dan pengembang yang terkait dengan aspek fleksibilitas dari SIMP.

\section{Perspektif Pengguna}

Berikut adalah beberapa hal yang menjadi concern pengguna dalam pengembangan SIMP.

a. SIMP harus dapat meng-cover seluruh aktivitas yang dilakukan pada proses bisnis pelatihan yang diselenggarakan, terutama pada bagian administrasi dan manajemen pelatihan yang sebelumnya dilakukan secara manual.

b. SIMP harus mengadopsi strategi flexibility-to-use, terutama yang berhubungan dengan variabilitas (keragaman) dari course pada suatu paket pelatihan yang ditawarkan, tujuan dari penyelenggaraan pelatihan, dan personal request dari peserta pelatihan.

c. SIMP harus mengadopsi strategi flexibility-tochange, karena adanya keterbatasan waktu dalam proyek, maka sistem yang dibuat harus dapat dengan mudah diubah atau ditambah fiturnya.

Adapun yang disediakan oleh pengguna dalam pengembangan SIMP untuk mencapai harapan di atas adalah:

a. Waktu dan biaya relatif cukup

b. Tim adhoc yang bertugas membantu tim pengembang dalam melakukan analisa dan pengujian sistem. Kelemahan yang terjadi, tim adhoc kurang memiliki pengetahuan tentang proses bisnis.

c. Calon operator yang disediakan memiliki IT literacy yang rendah.

\section{Perspektif Pengembang}

Dari sisi pengembang, hal-hal yang disediakan antara lain: a. Tidak memiliki kumpulan profesi yang lengkap, hanya terdiri atas system analyst, programmer, dan system tester engineer.

b. Memiliki framework pengembangan sistem informasi sendiri.

Berikut adalah hasil dari pengembangan SIMP dan analisis singkat terkait dengan perspektif pengguna dan pengembang yang telah dipaparkan sebelumnya.

a. SIMP mampu meng-cover proses bisnis pelatihan dengan batasan-batasan tertentu.

Karena faktor ketersediaan SDM di pihak pengguna (IT literacy rendah) dan di pihak pengembang (profesi kurang lengkap), maka SIMP yang dihasilkan tidak memenuhi strategi flexibility-touse.

b. SIMP memenuhi strategi flexibility-to-change dengan batasan tertentu.

Salah satu cara pandang pengembang (seperti yang disebutkan pada bagian perspektif pengembang di halaman 5) adalah menjadikan proyek pengembangan sistem informasi sebagai prospek untuk mendapatkan pekerjaan pemeliharaan sistem informasi tersebut.

Dengan menggunakan framework sendiri dalam mengembangkan SIMP, maka strategi flexibility-tochange dapat dilaksanakan dengan syarat tim yang akan melakukan perubahan harus paham tentang framework tersebut.

Dari hasil tersebut dapat disimpulkan bahwa pekerjaan pembangunan SIMP kurang memenuhi harapan yang ingin dicapai.

\section{Kesimpulan}

Pada tulisan ini, penulis menghubungkan karakteristik proses bisnis dengan strategi penerapan fleksibilitas sistem informasi. Penulis mencoba untuk meninjau perspektif pengguna dan pengembang dalam pemanfaatan strategi fleksibilitas sistem informasi untuk perbaikan kinerja proses bisnis organisasi.

Sebagai kesimpulan sementara yang dapat disampaikan adalah dalam pembangunan sistem informasi yang menggunakan asas fleksibilitas, peran pengguna tidak dapat dipisahkan dari kesuksesan. Persiapan yang tidak matang dari kedua belah pihak, baik pengguna maupun pengembang dapat menyebabkan kurang maksimalnya hasil yang diraih 


\section{Referensi}

[1] Gebauer, J., \& Schober, F. (2006). Information System Flexibility and the Cost Efficiency of Business Processes. Journal of the Association for Information Systems, 7(8), 122-147.

[2] Gebauer, J., \& Lee, F. (2007). Enterprise System Flexibility and Implementation Strategies: Aligning Theory with Evidence from a Case Study. Information Systems Management, 25, pp. 71-82.

[3] Gebauer, J., \& Schober, F. (2008). How Much to Spend on Flexibility? Determining the Value of Information System Flexibility. Working Paper.

[4] Fitzgerald, G., Barad, M., Papazafeiropoulou, A., \& Alaa, G. Generic Concept of Flexibility. 19th International Conference on Production Research.

[5] Nelson, K. M.,\& Nelson H. J.(1997). Technology Flexibility: Conceptualization, Validation, and Measurement. Proceedings of the 30th Hawaii International Conference on SystemSciences (HICSS) Volume 3: Information System Track-Organizational Systems andTechnology.

[6] Gwanhoo, L. Information Systems Project Flexibility:A Conceptual Development and Empirical Examination.Doctoral Thesis Proposal, University of Minnesota. 